\title{
Indonesia's Interest in ASEAN + 3 towards National Economic Improvement
}

\author{
Renny Miryanti, Tundjung Linggarwati \\ International Relations Department, Jenderal Soedirman University \\ renny.miryanti@gmail.com, tunjung.el@gmail.com
}

\begin{abstract}
The regional cooperation of ASEAN + 3 is a part of ASEAN cooperation improvement with their main three trading partners in East Asia which are China, Japan, and Korea. Mostly, their cooperation which focused on economic cooperation agendas became a very crucial matter in Indonesian foreign policy implementation.Increasing market access, trade volume, production, and investment are the main priorities for Indonesia's government towards ASEAN + 3. In addition, increasing mobility of labours, goods, services and capital are also the important things in supporting ASEAN + 3 trading partnership.
\end{abstract}

Keywords: ASEAN + 3, Foreign Policy, Indonesia, Trading Partnership

\section{Introduction}

Globalization is not only open the boundaries of relationship among states thus made territorial limitation not an obstacle in conducting international relation, also give a rise to a new phenomenon which is the strengthen of regionalism in some parts of the worlds, specifically in establishing free trade and security cooperation. Indonesia, which located in South East Asia region is not fall from that regionalism tendency, particularly in Asosiation of South-east Asia Nations (ASEAN).A intra-regional governmental organization, which in recent year establish regional cooperation with China, Japan and South Korea. This development leads to some adjustment in Indonesia foreign policy, mainly ones that concern with ASEAN+3 regionalism.

\section{Method}

This study use desk research method which based on secondary data and use the change and adjustment in foreign policy theory as analytical framework.

\section{Result And Discussion}

\subsection{Regionalism}

Regionalism or regional agglomeration is identified by geography proximity, cultural proximity, commerce and mutual economic interdependency, communication and participation in international organization. (Hopskin and Mansbaach: 1973). Therefore there are some elements that construct regionalism; those are geographic, cultural, commerce, economic interdependency, communication, and participation in international organization.

Meanwhile, regionalism itself has five criterias which are socio-cultural homogeneity, resemblance in political attitude or external behavior - usually projected in UN vote-, same membership in supranational or inter-government organization and economic interdependency which measured by regional trade as trade proportion and geographic proximity which measured by the flight distance among capitals (Bruce Russet dalam Andre H. Pareira: 1999:154). Based on above criterias, economic interdependency becomes more important than geographic concern. This lead to notion that regional establishment tends to about economic interest.

Regression in classic regionalism, which emphasized on military cooperation - the high politics, gave rise to the new forms of regionalism in accordance with changes in international political constellationpost-cold war era, which 
made regional cooperation revolve around economic interest and socio-cultural aspect, thelow politics.

There are four factors that gave impetus to the rise of new regionalism (1) The end of Cold War (2) Changes in world economic aspects (3) Decline of third world concept and(4) Democratization (Fawcett in Nuraeni S et. Al.:2010:20). The end of Cold War makes an end to ideological influence seizure by superpower state thus the changes international politic constellation become decentralized. Democratization issues also give a rise to equality demand. This situation is also characterized by the change of attitude by international actors in perceive multilateral cooperation thus gave birth open regionalism term.

The changes in world economic order, which based on the perspective that regional economic problem is no less important than regional - given the large scoop that regional economic problem covers such as the fulfillment of human basic needs, including foods, clothes, health, education, etc-, is create a view that wish the economic activity in given region shall continue regardless any political tension in region. This mutual economic cooperation could be an impetus to a new regionalism which accommodates the global trends such as free trade, common market, single market, etc. Meanwhile these changes also propelled by democratization, which create openness in the relations with other states, and acceptance of other states as an equal partner.

In the process to observe the differentiating character between classic regionalism and new regionalism, it is best shown in the table below.

\begin{tabular}{|l|l|l|}
\hline Category & \multicolumn{1}{|c|}{ Classic Regionalism } & \multicolumn{1}{c|}{ New Regionalisme } \\
\hline 1 & $\begin{array}{l}\text { Developed in Cold War era, based on } \\
\text { ideological and security calculation }\end{array}$ & $\begin{array}{l}\text { Developed in Post Cold War era (early } \\
1990 \mathrm{~s}), \text { based on multipolar structure } \\
\text { interactions. }\end{array}$ \\
\hline 2 & $\begin{array}{l}\text { Regionalism initiatives comes from super } \\
\text { power state }\end{array}$ & $\begin{array}{l}\text { State initiative based on each state needs of } \\
\text { cooperation as a respond to global change. } \\
\text { Thus view regionalism as an instrument to } \\
\text { achieve mutual interest. }\end{array}$ \\
\hline 3 & $\begin{array}{l}\text { Inward looking and protectionist } \\
\text { spen regionalism and more adapt to the } \\
\text { increasingly interdependent economic world }\end{array}$ \\
\hline 4 & $\begin{array}{l}\text { Specific scoop of action. e.g. NATO as a } \\
\text { Socus interactiononly on state actors }\end{array}$ & Comprehensive and Multi-Dimensional \\
\hline 5 & Yanyan M. Yani dan AA Banyu &
\end{tabular}


From the table, we could see there are changes in the basic of the regionalism establishment, orientation, initiative, the activity that it's cover and the development in involving non-state actors in the region.

\subsection{Indonesia Foreign Policy and Regionalism}

In the regard to the development of regionalism and the development of the ASEAN+3, Indonesia respondstothose developments as inputs and factors on change or adjusts its foreign policy. As explained in the adaptive model of foreign policy, a state will respond to any obstacle or opportunity that caused by the changing of its external environment. Generally speaking, this adaptive model separate between the capability and national power of a state, but give more emphasizes on how state respond to the development in its external environment. James N. Rosenau (1974:47) gave farther explanations:

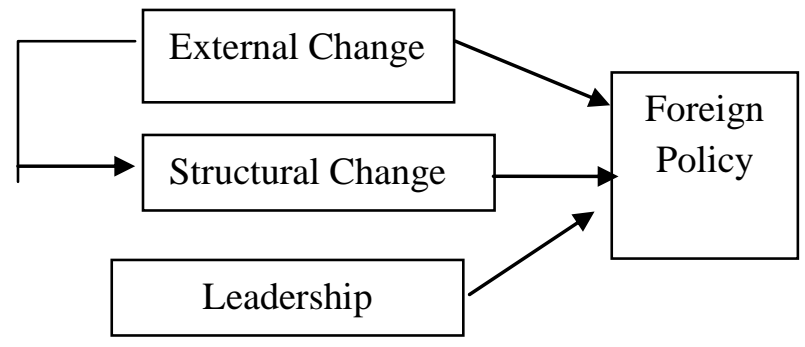

In this model, we could see that foreign policy is an action that made as consequences or responses to the change in external and internal environment (structural change). Or in other word there are two important variables that determine the foreign policy action, external and internal change which supported by leadership variable

Regarding the change in international politic constellation, especially the tendency for strengthening regionalism, foreign policy is also change accordingly. Charles F. Hermann (1990) believe that change in certain state's foreign policy could categorized in four (1) Adjustment changes, (2) Program Changes, (3)Problem?goal changes, (4) International orientation changes. Furthermore Charles F Hermann explain that the change in foreign policy is triggered by many actor such (1)leader driven, (2) bureaucratic advocacy, (3)domestic restructuring and (4) external shock.

This adjustment refer to quantitative changing rather than qualitative. While nation-state may also change their goal and foreign policy orientation based on their national interest and contemporary internal and external condition. There are several steps that a nation-state may take in changing or adjusting their foreign policy which are: 1)Initial policy expectation, 2)external actor/environment stimuli,3)recognition of discrepant information, 4)postulation of connection between problem and policy, 5)Development of alternatives 6)building authoritative consensus for choice, 7)Implementation of new policy (Charles F. Hermann:1990).

\subsection{Change Indonesia Foreign Policy Regarding ASEAN+3 Cooperation}

Indonesia foreign policy, which previously adopt low profile approach especially with South East Asia Countries by its slogan 'good neighbor policy' that refers to security interest or particularly territorial security where Indonesia believe that neighboring countries will help in its territorial defense strategy, recently became an high profile one especially in the ever increasing ASEAN activity in the accordance with ASEAN Community and the development in ASEAN cooperation including ASEAN+3. The shift in regional issue that became dominated by economic and free market issue as an effort to gain recovery after the slumped economy post 1998 economic crisis 
also leadership variable that believe the need for adjustment in accordance to the increase of regional bargain position that make the change happen in the first place.

Indonesia's desire to increase the status as regional power is realized, partially, in its ASEAN leadership in 2011 and as host for APEC summit 2013. However the regional power status is not only determined by trust from regional institution, such as appointment as leader, but also determined by economic growth, political stability, and the stability of national security, whether internal or external relations with other countries. This is in accordance with the main operational tenet in Rencana Pembangunan Jangka Menengah Nasional (RPJM) or Long Term National Development Plan 2010 - 2014 that positioned ASEAN cooperation as an important factor in attempt to increase international cooperation by using opportunities that it have. (Tundjung Linggarwati: 2012)

ASEAN+3 cooperation that implement great number of cooperation in many sectors such as food security, trade and economy, disaster management, financial cooperation, education,tourism promotion and cooperation in fighting against transnational crimebecame very important propeller for Indonesia to be more focus in development of regional cooperation, considering the great interest of Indonesia in ASEAN cooperation partner countries. Indonesia - China trade volume as 2012 reach USD 6.6 billion, or three times the similar trade volume in 2010. In accordance with that the China investment flow in Indonesia has reach USD 2.2 billion per 2012. Indonesia set the target for 2015 that its trade volume with China will reach USD 80 billion. This target is a small one if compared to the other ASEAN countries, e.g. Malaysia that set USD 180 billion worth trade with China in the same period. As for now Malaysia-China Trade is worth about USD 100 billion. http://beritadaerah.com/2013/11/01/indonesia -seimbangkan-neraca-perdagangan-dengan-china/).

Japan is the Indonesia second largest export market after China. As per September 2011 Indonesia export to China was worth USD 14.90 Billion and as export for Japan wasUSD13.63billion. Meanwhile USis in the top three with USD 11.84 billion worth export in the same period.Eksport per August reach USD 22.99 billion, that consisted by USD 11.06 billion from oil and gas export and USD 11.93 billion from non-oil and gas Sector. As for the import, it reachesUSD 12.13 billion, consisted by USD 30.67 million of oil and gas import and USD 12.10 billion from non-oil and gas sector. (http://indostrategic.com/?p=375, 28 November 2011)

Indonesia-South Korea trade in 2011 was worth USD 29.4 billion with USD 16.4 billion of export and USD 12.9 miliar of import, or rise 44,93\% from the 2010 trade which worth USD 20.3 billion. The total trade trend for the last five year (2007-2011) give positive sign with $25.11 \%$. Indonesia-South Korea trade balance from 2007 till 2011 shows that Indonesia get surplus, as for 2011 the surplus reach USD 3.4 billion. Indonesia main export commodities to South Korea are coal; briquettes; copper ores; chemical wood pulp; natural rubber; balata; paper and paperboard; plywood; cotton yarn; coconut; palm kernel as well as manufactured products such as footwear; textiles and garments; and furniture. Meanwhile Indonesia main import from South Korea are suitable for use solely; electronic application for line telephony; synthetic rubber; electronic integrated circuits; and other knitted or crocheted fabrics; woven fabrics of synthetic filament yarn; and polyacetals, other polyethers. In Investment sector, 
South Korea is the sixth largest investor in Indonesia with USD 3.35 billion worth investment in the last ten year (2000-2010) with 1,400 project. As 2011, South Korea was the fifth largest investor with USD1.2 billion worth investment. (http://ditjenkpi.kemendag.go.id/website_kpi/index.p $\underline{\text { hp? } \text { module}=\text { news_detail\&news_content_id=1009\&de }}$ $\underline{\text { tail=true) }}$

According to above facts, it could be concluded that Indonesia is reasonable to adjust its foreign policy in ever changing external development, the strengthening of ASEAN regionalism with its cooperation partner in ASEAN+3. Those adjustment were found in the Arah Pembangunan Jangka Panjangor Direction of Long-Term Development 2005-2025 about foreign policy which said "In order to achieve advanced, independent and just Indonesia, it is very important in Indonesia foreign policy and other cooperation whether in regional or international level considering the ever fast changing political and international relation situation." This is implemented in Indonesia active participation in number of regional cooperations especially in ASEAN+3 framework where its cooperation development will increase Indonesia economic performance and prosperity.

\section{Conclusion}

Regionalism is one of the current developments that every country, including Indonesia, needs to respond. The rise of new regionalism gives new opportunities and expand cooperation sphere. ASEAN+3 cooperationbecomes very important for Indonesia because it contains great number of cooperation in economic sectors, which expected to propel the increase of trade volume and strengthening other cooperation.Change in Indonesia foreign policy accommodate the external environment change thus could optimize the opportunity that created by external change by adjust its foreign policy.

\section{References}

1) Hermann, Charles F. (1990). Changing Course; When Government Choose to Redirect Foreign Policy. International Studies Quarterly, 34 (1)

2) Hopskin, Raymond F and Richard W, Mansbaach. (1973).Structure and Proccess in International Politics. United State: Harper and Row Publisher

3) Linggarwati, Tundjung (2012). Optimalisasi Multitrack Diplomasi Melalui Sinkronisasi Kebijakan untuk Mendukung Pelaksanaan Politik Luar Negeri; Sebuah Upaya untuk mencapai Status Regional Power dalam Desain Besar Politik Luar Negeri, Rangkuman Kegiatan Diskusi dan Monev Asdep Hubungan Internasional Tahun 2012, Jakarta.

4) Nuraeini, Daesy Silvya dan Arifin Sudirman. (2010).Regionalisme. Yogyakarta: Pustaka Pelajar

5) Pareira, Andre H. (1999).Perubahan Global dan Perkembangan Studi Hubungan Internasional. Bandung: PT.Citra Aditya Bakti

6) Rosenau, James N. (1974).Comparing Foreign Policy, Theories, Findings and Methods. New York: Sage Publications

7) Yani, Yanyan M dan AA Banyu Perwita. (2005). Pengantar Ilmu Hubungan Internasional. Bandung: PT Remaja Rosdakarya

8) http://beritadaerah.com/2013/11/01/indonesiaseimbangkan-neraca-perdagangan-dengan-china/ accessed April,4 2014

9) http://indostrategic.com/?p=375, 28 November 2011 accessed April,4, 2014

10)http://ditjenkpi.kemendag.go.id/website_kpi/index . php? module $=$ news_detail\&news_content_id $=100$ 9\&detail=true accessed April, 4, 2014 